\title{
Manganese Ion-dependent Production of Phosphodiesterase by Alkalophilic Bacillus No. A-40-2 and Its Properties
}

\author{
Yoko IKuRA and Koki HorikosHI \\ The Institute of Physical and Chemical Research, \\ Wako-shi, Saitama 351-01, Japan \\ Received June 7, 1990
}

\begin{abstract}
Phosphodiesterase production with bis-p-nitrophenyl phosphate as a substrate by alkalophilic Bacillus No. A-40-2 increased with increasing $\mathrm{Mn}^{2+}$ concentration, showing maximum productivity at $10 \mathrm{~mm}$. The enzyme production was negligible in the medium without $\mathrm{Mn}^{2+}$. The simultaneous addition of $10 \mathrm{mM} \mathrm{Mn}{ }^{2+}$ and one of the several cations $\mathrm{Mg}^{2+}, \mathrm{Co}^{2+}, \mathrm{Mo}^{6+}$, and $\mathrm{Pb}^{2+}$ at suitable concentrations stimulated the enzyme production 1.8 -fold at most over that with only $10 \mathrm{mM} \mathrm{Mn}^{2+}$. Inorganic phosphate hardly repressed the enzyme production. The enzyme was purified homogeneously. The purified enzyme had the optimum $\mathrm{pH}$ of 7.5 and was fairly stable from $\mathrm{pH} 7-11$. The enzyme hydrolyzed $2^{\prime}, 3^{\prime}$-cyclic-nucleotides and $3^{\prime}$-nucleotides, but did not hydrolyze $3^{\prime}, 5^{\prime}$-cyclic-nucleotides or $5^{\prime}$-nucleotides, indicating it to be a $2^{\prime}, 3^{\prime}$-cyclic-nucleotide $2^{\prime}$-phosphodiesterase (EC 3.1.4.16). The enzyme had activity without metals, but $\mathrm{Mg}^{2+}, \mathrm{Ca}^{2+}, \mathrm{Ba}^{2+}$, and $\mathrm{Mo}^{6+}$ activated the enzyme reaction.
\end{abstract}

We reported on the manganese iondependent production of $5^{\prime}$-nucleotidase by alkalophilic Bacillus. ${ }^{1)}$ Up to date, phosphodiesterase (2',3'-cyclic-nucleotide 2'-phosphodiesterase, EC 3.1.4.16) has been found in a number of strains of Escherichia coli, ${ }^{2)}$ Enterobacteriaceae, ${ }^{3)}$ Vibrio alginolyticus, ${ }^{4)}$ and $\mathrm{Ba}$ cillus subtilis. ${ }^{5,6)}$ A variety of properties of phosphodiesterases of various organisms have been reported, but little has been reported on phosphodiesterase of alkalophilic microorganisms. Here we describe the extracellular production of phosphodiesterase by an alkalophilic Bacillus sp. depending on manganese ions in the growth medium, and the purification and some properties of the enzyme.

\section{Materials and Methods}

Culture conditions. A medium with the following composition was used as the standard medium $(\mathrm{g} / 1)$ : soluble starch, 15; $\left(\mathrm{NH}_{4}\right)_{2} \mathrm{SO}_{4}, 5 ; \mathrm{MgSO}_{4} \cdot 7 \mathrm{H}_{2} \mathrm{O}, 0.2$; $\mathrm{MnCl}_{2}-4 \mathrm{H}_{2} \mathrm{O}, 0.02$; and $\mathrm{NaHCO}_{3}, 10$. The $\mathrm{NaHCO}_{3}$ was sterilized separately. The microorganism was cultured in $50 \mathrm{ml}$ of medium in a $300-\mathrm{ml}$ two-tucked flask after inoculation with $0.5 \mathrm{ml}$ of overnight culture at $37^{\circ} \mathrm{C}$ on a rotary shaker $(200 \mathrm{rpm})$.
Enzyme assay. Phosphodiesterase activity was measured by the amount of $p$-nitrophenol released from bis- $p$ nitrophenyl phosphate (BisPNPP) at $40^{\circ} \mathrm{C}$ in $15 \mathrm{~min}$. The reaction mixture contained, in a total volum of $0.5 \mathrm{ml}$ : $0.2 \mathrm{ml}$ of $0.1 \mathrm{M}$ HEPES-KOH buffer (pH 8.0), $0.01-0.05 \mathrm{ml}$ of culture supernatant, $0.1 \mathrm{ml}$ of $10 \mathrm{~mm}$ BisPNPP, and $0.15-0.19 \mathrm{ml}$ of distilled water. The reaction was started by adding BisPNPP solution, stopped by the addition of $0.05 \mathrm{ml}$ of $1 \mathrm{~N} \mathrm{NaOH}$, and diluted with $3.0 \mathrm{ml}$ of distilled water. The absorbance at $410 \mathrm{~nm}$ was measured. One unit of enzyme activity was defined as the amount of enzyme that released $1 \mu \mathrm{mol}$ of $p$-nitrophenol per min under these conditions.

Cyclic phosphodiesterase and nucleotidase were assayed at $40^{\circ} \mathrm{C}$ for $15 \mathrm{~min}$ by measuring the phosphate liberated from the respective substrates listed in Table IV, as stated above. Alkaline phosphatase with BisPNPP as a substrate, or alkaline phosphatase and purified $5^{\prime}$-nucleotidase of Bacillus No. A-59 ${ }^{17}$ with $3^{\prime}, 5^{\prime}$-cyclic-nucleotides were added to the reaction mixture. The reaction was stopped by the addition of $0.3 \mathrm{ml}$ of $6 \mathrm{~N} \mathrm{H}_{2} \mathrm{SO}_{4}$. Phosphate was measured by the method of Fiske and Subarrow, with some modifications, described previously. ${ }^{1)}$ One unit of enzyme activity was defined as the amount of enzyme that released $1 \mu \mathrm{mol}$ of inorganic phosphate permin.

Alkaline phosphatase was assayed by the previously described method. ${ }^{7)}$

Protein measurement. Protein was measured by the method of Lowry et al., ${ }^{87}$ with bovine serum albumin as standard protein. 
SDS-Polyacrylamide gel electrophoresis. Electrophoresis was done at $30 \mathrm{~mA}$ for $2.5 \mathrm{hr}$ at $\mathrm{pH} 8.3$ using a SDS-PAGE plate 4/20 from Daiichi Pure Chemicals Co., Ltd. (Tokyo). The gel was stained with Coomassie brilliant blue.

Molecular weight measurement. The molecular weight of the phosphodiesterase was measured by the method of Andrew $^{9)}$ on a column $(1.5 \times 100 \mathrm{~cm})$ of Cellulofine GCL-1000-sf which had been equilibrated with $0.05 \mathrm{M}$ Tris-HCl buffer, pH 7.2.

Chemicals. Cyclic nucleotides and mononoculeotides were obtained from Sigma Chemical Co. (St. Louis, Mo., U.S.A.) and yeast extract from Difco Laboratories (Detroit, Mich, U.S.A.). All other chemicals were of reagent grade.

\section{Results}

$\mathrm{Mn}^{2+}$-dependent production of phosphodiesterase

Of the alkalophilic strains isolated in our laboratory, No. A-40-2, ${ }^{10)}$ an alkaline amylase producer, was chosen due to its phosphodiesterase productivity. Phosphodiesterase was found mainly in the culture supernatant and slightly in the cell-free extract. The enzyme activity levelled off between $20-35 \mathrm{hr}$ of cultivation in the standard medium. The enzyme production increased with increasing $\mathrm{Mn}^{2+}$ concentration, with maximum productivity at $10 \mathrm{~mm}$. As shown in Fig. 1, phosphodiesterase production was negligible in the medium without $\mathrm{Mn}^{2+}\left(\mathrm{MnCl}_{2}\right.$-omitted standard me- dium). The other cations $\mathrm{Ca}^{2+}, \mathrm{Ba}^{2+}, \mathrm{Mg}^{2+}$, $\mathrm{Co}^{2+}, \mathrm{Fe}^{2+}, \mathrm{Mo}^{6+}, \mathrm{Zn}^{2+}, \mathrm{Ni}^{2+}$, or $\mathrm{Pb}^{2+}$, added singly at $0.1,1.0$, or $10 \mathrm{~mm}$, had no stimulatory effect on phosphodiesterase production. Alkaline phosphatase production that was observed in the standard medium was not increased with increasing $\mathrm{Mn}^{2+}$.

\section{Effects of simultaneous addition of $\mathrm{Mn}^{2+}$ and other cations}

The enzyme activity was assayed after the culture fluid was dialyzed against water for $5 \mathrm{hr}$. The simultaneous addition of $10 \mathrm{~mm} \mathrm{Mn}^{2+}$ and one of the several cations $\mathrm{Mg}^{2+}, \mathrm{Co}^{2+}, \mathrm{Mo}^{6+}$ and $\mathrm{Pb}^{2+}$ stimulated the phosphodiesterase production 1.8-fold at most (Table I). The other cations, $\mathrm{Ca}^{2+}, \mathrm{Ba}^{2+}, \mathrm{Fe}^{2+}$, and $\mathrm{Zn}^{2+}$, added simultaneously with $10 \mathrm{~mm} \mathrm{Mn}^{2+}$, repressed phosphodiesterase production slightly or appreciably.

Effects of inorganic phosphate on the enzyme production

As shown in Table II, $1 \mathrm{mM} \mathrm{K}_{2} \mathrm{HPO}_{4}$ increased the enzyme production to a certain extent and $10 \mathrm{~mm} \mathrm{~K}_{2} \mathrm{HPO}_{4}$ repressed the enzyme production only by $15 \%$.

\section{Purification and molecular weight of phospho- diesterase}

All purification procedures were done below

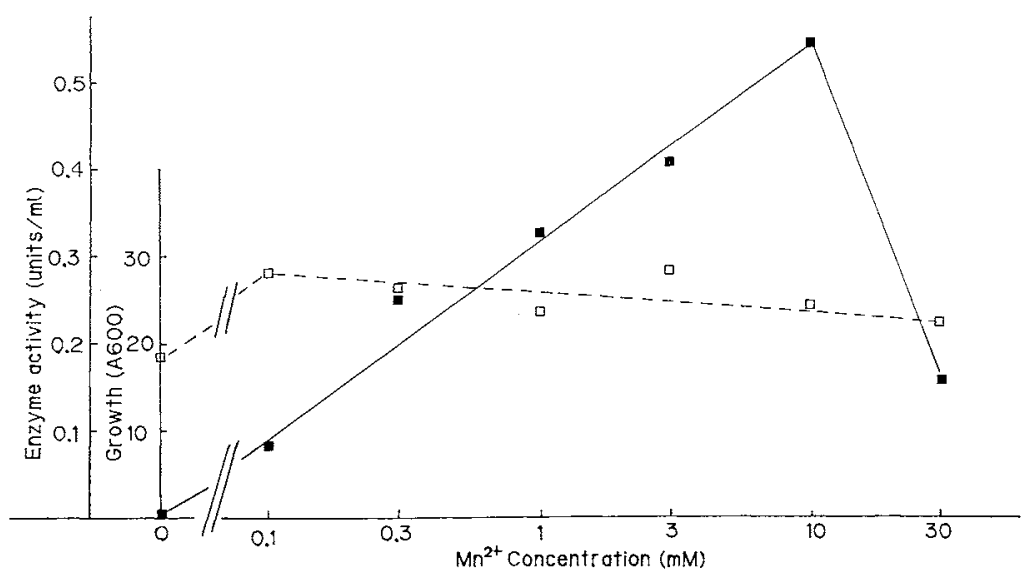

Fig. 1. Stimulatory Effect of $\mathrm{Mn}^{2+}$ on the Production of the Phosphodiesterase.

The enzyme activity was assayed after $24 \mathrm{hr}$ of cultivation. $\square$, growth; $\mathbf{D}$, enzyme activity. 
$5^{\circ} \mathrm{C}$. The enzyme solution was concentrated with a Diaflow membrane PM 10 throughout the purification. Table III summarizes the purification. The culture supernatant after

Table I. EfFects of Simultaneous Addition OF $\mathrm{Mn}^{2+}$ and Various Metals on Phosphodiesterase Production

\begin{tabular}{lccc}
\hline Metal added & $\begin{array}{c}\text { Concentra- } \\
\text { tion } \\
(\mathrm{mM})\end{array}$ & $\begin{array}{c}\text { Growth } \\
\left(A_{600}\right)\end{array}$ & $\begin{array}{c}\text { Enzyme } \\
\text { activity } \\
\text { (units/m1) }\end{array}$ \\
\hline None & - & 24.5 & 0.478 \\
$\mathrm{MgCl}_{2}$ & 5 & 27.6 & 0.559 \\
& 10 & 27.5 & 0.541 \\
& 20 & 26.2 & 0.627 \\
$\mathrm{Co}\left(\mathrm{NO}_{3}\right)_{2}$ & 30 & 25.7 & 0.566 \\
& 0.05 & 24.8 & 0.501 \\
& 0.2 & 23.9 & 0.844 \\
$\mathrm{Na}_{2} \mathrm{MoO}_{4}$ & 1 & 18.6 & 0.459 \\
& 5 & 8.7 & 0.022 \\
$\mathrm{PbCl}_{2}$ & 5 & 20.4 & 0.714 \\
& 10 & 19.8 & 0.841 \\
& 20 & 19.4 & 0.857 \\
& 0.1 & 20.3 & 0.650 \\
& 1 & 6.5 & 0.034
\end{tabular}

Each medium contained $10 \mathrm{~mm} \mathrm{Mn}^{2+}$. The enzyme activity was assayed after $24 \mathrm{hr}$ of cultivation.

Table II. EFfects of InORganic Phosphate on the Phosphodiesterase Production IN THE PRESENCE of $10 \mathrm{~mm} \mathrm{Mn}^{2+}$

\begin{tabular}{cccc}
\hline $\begin{array}{c}\mathrm{K}_{2} \mathrm{HPO}_{4} \\
\begin{array}{c}\text { concentration } \\
(\mathrm{mM})\end{array}\end{array}$ & $\begin{array}{c}\text { Growth } \\
\left(A_{600}\right)\end{array}$ & $\begin{array}{c}\text { Enzyme } \\
\text { activity } \\
\text { (units/ml) }\end{array}$ & $\begin{array}{c}\text { Relative } \\
\text { activity } \\
(\%)\end{array}$ \\
\hline 0 & 21.9 & 0.514 & 100 \\
0.1 & 20.5 & 0.523 & 102 \\
1 & 18.0 & 0.613 & 119 \\
10 & 15.7 & 0.436 & 85 \\
\hline
\end{tabular}

The enzyme activity was assayed after $24 \mathrm{hr}$ of cultivation.
$24 \mathrm{hr}$ of cultivation with $10 \mathrm{~mm} \mathrm{Mn}^{2+}$ was concentrated to about one fifth of the initial volume with polyethyleneglycol 6000 . The concentrated enzyme solution was dialyzed for 2 days against $0.05 \mathrm{~m}$ Tris $-\mathrm{HCl}$ buffer, $\mathrm{pH} 8.0$, with a change of the buffer solution. The dialyzed solution was put on a DEAEToyopearl $650 \mathrm{M}$ column $(1.5 \times 40 \mathrm{~cm})$ equilibrated with the buffer described above. After the column had been washed with the same buffer, the enzyme was eluted with a linear gradient of $\mathrm{NaCl}(0-0.5 \mathrm{M})$ in the equilibration buffer (total volume $300 \mathrm{ml}$ ). The active fraction $(35 \mathrm{ml})$ was concentrated and dialyzed against the equilibration buffer. The second DEAE-Toyopearl chromatography was done by the same procedure. For the gel filtration experiment, the concentrated enzyme solution was put on a column $(1.5 \times 40 \mathrm{~cm})$ of Sephacryl S-300 equilibrated with $0.05 \mathrm{~mm}$ Tris $-\mathrm{HCl}$ buffer ( $\mathrm{pH} 8.0$ ) containing $0.05 \mathrm{~mm} \mathrm{Co}\left(\mathrm{NO}_{3}\right)_{2}$, which stabilized the enzyme at low temperatures for a long time. The homogeneity of the purified enzyme was confirmed by the SDS-

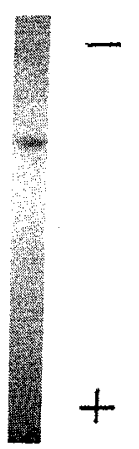

Fig. 2. Electrophoretic Profile of the Enzyme in an SDS-Polyacrylamide gel.

The gel was stained with Coomassie brilliant blue.

Table III. Summary of the PURIFICATION

\begin{tabular}{lcccc}
\hline & $\begin{array}{c}\text { Total activity } \\
\text { (units) }\end{array}$ & $\begin{array}{c}\text { Total protein } \\
(\mathrm{mg})\end{array}$ & $\begin{array}{c}\text { Specific activity } \\
\text { (units/mg protein) }\end{array}$ & $\begin{array}{c}\text { Recovery } \\
(\%)\end{array}$ \\
\hline Culture fluid & 11.09 & 170.1 & 0.0652 & 100 \\
Polyethyleneglycol and dialysis & 7.98 & 36.5 & 0.219 & 72 \\
First DEAE-Toyopearl & 7.43 & 1.81 & 4.10 & 67 \\
Second DEAE-Toyopearl & 6.76 & 1.12 & 6.04 & 61 \\
Sephacryl S-300 & 5.65 & 0.437 & 12.93 & 51 \\
\hline
\end{tabular}




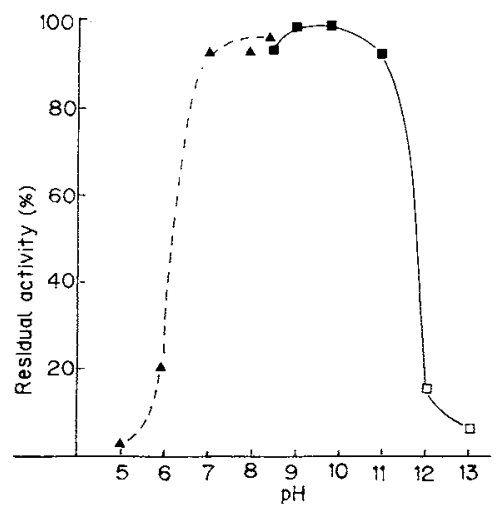

Fig. 3. pH Stability of the Phosphodiesterase.

The enzyme was treated in each buffer at $40^{\circ} \mathrm{C}$ for $15 \mathrm{~min}$. After the $\mathrm{pH}$ had been adjusted to 8.0 with an $\mathrm{HCl}$ or $\mathrm{KOH}$ solution, the residual activity was measured by the standard assay method. The buffer systems were as follows: $0.1 \mathrm{M}$ HEPES-KOH (pH $5.0-8.5, \boldsymbol{\Delta}), 0.1 \mathrm{M} \mathrm{KHCO}_{3}$ $\mathrm{K}_{2} \mathrm{CO}_{3}(\mathrm{pH} 8.5-11.0$, $)$, and $0.1 \mathrm{M} \mathrm{K}_{2} \mathrm{CO}_{3}-\mathrm{KOH}(\mathrm{pH}$ 12.0 and $13.0, \square)$.

polyacerylamide gel electrophoresis shown in Fig. 2. It molecular weight estimated by gel filtration on Cellulofine GCL-1000-sf column $(1.5 \times 100 \mathrm{~cm})$ was 122,000 and that by SDS-PAGE was 120,000 .

Effects of $\mathrm{pH}$ and temperature on activity and stability

The optimum $\mathrm{pH}$ for the enzyme activity was 7.5. Figure 3 shows the $\mathrm{pH}$ stability. The enzyme was fairly stable over the $\mathrm{pH}$ range of 7-11. The enzyme had an optimum temperature of $40-45^{\circ} \mathrm{C}$ in the $\mathrm{pH} 7.5 \mathrm{HEPES}-\mathrm{KOH}$ buffer for $15 \mathrm{~min}$ of incubation, and had $100 \%$ activity at $35^{\circ} \mathrm{C}$ after treatment for $15 \mathrm{~min}$ at $\mathrm{pH} 7.5$.

\section{Substrate specificity}

We investigated the phosphodiesterase with BisPNPP as a substrate, but there are several types of phosphodiesterases by their specificities. Table IV shows the relative activity for different kinds of nucleotides. The enzyme of this strain strongly hydrolyzed $2^{\prime}, 3^{\prime}$-cyclicnucleotides and $3^{\prime}$-nucleotides, but did not hydrolyze $3^{\prime}, 5^{\prime}$-cyclic-nucleotides and $5^{\prime}$-nucleotides, indicating that the enzyme is a $2^{\prime}, 3^{\prime}$ cyclic-nucleotide $2^{\prime}$-phosphodiesterase (EC
Table IV. Activity of Phosphodiesterase TOWARD VARIOUS SUBSTRATES

\begin{tabular}{lc}
\hline Substrate & $\begin{array}{c}\text { Relative activity } \\
(\%)\end{array}$ \\
\hline BisPNPP & 100 \\
$2^{\prime}, 3^{\prime}$-cyclic AMP & 278 \\
$2^{\prime}, 3^{\prime}$-cyclic CMP & 245 \\
$2^{\prime}, 3^{\prime}$-cyclic GMP & 253 \\
$2^{\prime}, 3^{\prime}$-cyclic UMP & 433 \\
$3^{\prime}, 5^{\prime}$-cyclic AMP & 0 \\
$3^{\prime}, 5^{\prime}$-cyclic CMP & 0 \\
$3^{\prime}, 5^{\prime}$-cyclic GMP & 0 \\
3',5'-cyclic UMP & 0 \\
3'-AMP & 217 \\
3'-CMP & 218 \\
3'-GMP & 404 \\
3'-UMP & 451 \\
2'-AMP & 0 \\
2'-GMP & 0 \\
5'-AMP & 0 \\
5'-CMP & 0 \\
5'-GMP & 0 \\
5'-UMP & 0 \\
5'-dAMP & 0 \\
5'-dGMP & 0 \\
ADP & 0 \\
ATP & 0 \\
$p^{\prime}$-Nitrophenyl phosphate & 0 \\
&
\end{tabular}

3.1.4.16). The Michaelis constant and $\mathrm{V}_{\max }$ for BisPNPP were $1.2 \mathrm{~mm}$ and $35 \mu \mathrm{mol} / \mathrm{min} / \mathrm{mg}$ protein, respectively.

\section{Effects of various reagents}

A mixture $(0.4 \mathrm{ml})$ consisting of $0.02 \mathrm{ml}$ of the enzyme solution dialyzed against distilled water, $0.2 \mathrm{ml}$ of $0.1 \mathrm{M}$ HEPES-KOH buffer $(\mathrm{pH}$ $8.0), 0.01-0.1 \mathrm{ml}$ of metal ion or EDTA solution, and $0.08-0.17 \mathrm{ml}$ of distilled water was incubated at $40^{\circ} \mathrm{C}$ for $15 \mathrm{~min}$. Then $0.1 \mathrm{ml}$ of the substrate was added. Table $\mathrm{V}$ summarizes the effects of reagents on enzyme activity. The enzyme had activity without metals, but $\mathrm{Mg}^{2+}, \mathrm{Ca}^{2+}, \mathrm{Ba}^{2+}$, and $\mathrm{Mo}^{6+}$ activated the enzyme reaction. EDTA slightly affected the enzyme activity.

\section{Discussion}

The extracellular production of a phosphodiesterase by alkalophilic Bacillus was en- 
Table V. EFFects of Various Compounds on the Hydrolysis of Phosphodiesterase

\begin{tabular}{|c|c|c|}
\hline Compound & $\begin{array}{l}\text { Concentration } \\
(\mathrm{mM})\end{array}$ & $\begin{array}{c}\text { Activity } \\
(\%)\end{array}$ \\
\hline None & - & 100 \\
\hline \multirow[t]{4}{*}{$\mathrm{MgCl}_{2}$} & 1 & 103 \\
\hline & 5 & 118 \\
\hline & 10 & 125 \\
\hline & 20 & 120 \\
\hline \multirow[t]{4}{*}{$\mathrm{CaCl}_{2}$} & 1 & 124 \\
\hline & 5 & 127 \\
\hline & 10 & 132 \\
\hline & 20 & 149 \\
\hline \multirow[t]{3}{*}{$\mathrm{BaCl}_{2}$} & 0.1 & 113 \\
\hline & 1 & 141 \\
\hline & 5 & 136 \\
\hline \multirow[t]{3}{*}{$\mathrm{Na}_{2} \mathrm{MoO}_{4}$} & 10 & 119 \\
\hline & 30 & 127 \\
\hline & 50 & 126 \\
\hline \multirow[t]{2}{*}{$\mathrm{MnCl}_{2}$} & 0.01 & 102 \\
\hline & 0.1 & 78 \\
\hline \multirow[t]{2}{*}{$\mathrm{Co}\left(\mathrm{NO}_{3}\right)_{2}$} & 0.01 & 99 \\
\hline & 0.1 & 82 \\
\hline $\mathrm{FeSO}_{4}$ & 0.1 & 76 \\
\hline $\mathrm{ZnSO}_{4}$ & 0.1 & 7 \\
\hline $\mathrm{NiSO}_{4}$ & 0.1 & 69 \\
\hline $\mathrm{PbCl}_{2}$ & 0.1 & 82 \\
\hline $\mathrm{CuSO}_{4}$ & 0.01 & 8 \\
\hline $\mathrm{CdSO}_{4}$ & 0.1 & 41 \\
\hline $\mathrm{SnCl}_{2}$ & 0.1 & 88 \\
\hline \multirow[t]{2}{*}{ EDTA } & 0.1 & 82 \\
\hline & 1.0 & 79 \\
\hline
\end{tabular}

hanced by the addition of a high concentration, $10 \mathrm{~mm}$, of $\mathrm{Mn}^{2+}$ to the culture medium. Several cations stimulated the enzyme production when added simultaneously with $10 \mathrm{~mm} \mathrm{Mn}^{2+}$. Ammonium sulfate was used as a nitrogen source bacause of its efficiency (data not shown). The role of a high concentration of $\mathrm{Mn}^{2+}, 10 \mathrm{~mm}$, in the enzyme production was not understandable exactly, but it may be involved in the triggering of the enzyme synthesis as in the case of $5^{\prime}$-nucleotidase. ${ }^{1)}$ There has been no report on stimulatory effects of $\mathrm{Pb}^{2+}$ on enzyme production, and it is of interest that high concentrations of $\mathrm{Mo}^{6+}$,
5-20 mM, stimulated enzyme production (Table II). In many cases, inorganic phosphate was added to the culture media for the production of phosphodiesterase, indicating that phosphodiesterase is constitutive. In this strain, the $\mathrm{Mn}^{2+}$-stimulated enzyme production was scarcely affected by inorganic phosphate.

The molecular weight of 120,000 was larger than those reported for other phosphodiesterases. ${ }^{11)}$ The optimum $\mathrm{pH}$ of 7.5 was similar to those of enzymes reported for neutrophilic strains. ${ }^{11)}$ The thermostability range of $\mathrm{pH}$ 7-11 shows a characteristic feature of the enzyme from an alkalophilic strain, although there has been no paper on the $\mathrm{pH}$ stability of phosphodiesterases. The optimum temperature and thermostability data shows the similarity to other phosphodiesterases. Several types of phosphodiesterases were known, and phosphodiesterase of this strain belongs to $2^{\prime}, 3^{\prime}$-cyclicnucleotide $2^{\prime}$-phosphodiesterase (EC 3.1.4.16) due to its substrate specificity. Cobalt ion stabilized the enzyme at $5^{\circ} \mathrm{C}$ for a long time ( $>1$ week), but it was not effective at $40^{\circ} \mathrm{C}$.

\section{References}

1) Y. Ikura and K. Horikoshi, Agric. Biol. Chem., 53, 645 (1989).

2) Y. Anraku, J. Biol. Chem., 239, 3412 (1964).

3) H. C. Neu and J. Chou, J. Bacteriol., 94, 1934 (1967).

4) T. Unemoto and M. Hayashi, Biochim. Biophys. Acta, 171, 89 (1969).

5) K. Shimada and Y. Sugino, Biochim. Biophys. Acta, 185, 367 (1969)

6) T. Seki and S. Fukuda, J. Gen. Appl. Microbiol, 27, 487 (1981).

7) Y. Ikura, J. Ferment. Bioeng., 69, 83 (1990).

8) O. H. Lowry, N. J. Rosebrough, A. L. Farr and R. J. Randall, J. Biol. Chem., 193, 265 (1951).

9) P. Andrew, Biochem. J., 96, 595 (1965).

10) K. Horikoshi, Agric. Biol. Chem., 35, 1783 (1971).

11) G. I. Drummond and M. Yamamoto, in "The Enzymes," Vol. 4, ed. by P. D. Boyer, Academic Press Inc., London, 1971, pp. 355-371. 